\title{
Minireview
}

\section{The role of early life genistein exposures in modifying breast cancer risk}

\author{
A Warri', NM Saarinen', S Makela ${ }^{1,3}$ and L Hilakivi-Clarke*,2 \\ ${ }^{\prime}$ Functional Foods Forum, University of Turku, Turku, Finland; ' ${ }^{2}$ Department of Oncology, Lombardi Cancer Center and Georgetown University, 3970 \\ Reservoir Road, NW, Washington, DC 20057, USA; ${ }^{3}$ Department of Biochemistry and Food Chemistry, University of Turku, Turku, Finland
}

Review of the existing literature suggests that consumption of soy foods or an exposure to a soy isoflavone genistein during childhood and adolescence in women, and before puberty onset in animals, reduces later mammary cancer risk. In animal studies, an exposure that is limited to the fetal period or adult life does not appear to have the same protective effect. A meta-analysis of human studies indicates a modest reduction in pre- and postmenopausal risk when dietary intakes are assessed during adult life. These findings concur with emerging evidence indicating that timing may be vitally important in determining the effects of various dietary exposures on the susceptibility to develop breast cancer. In this review, we address the mechanisms that might mediate the effects of an early life exposure to genistein on the mammary gland. The focus is on changes in gene expression, such as those involving BRCA I and PTEN. It will be debated whether mammary stem cells are the targets of genistein-induced alterations and also whether the alterations are epigenetic. We propose that the effects on mammary gland morphology and signalling pathways induced by pubertal exposure to genistein mimic those induced by the oestrogenic environment of early first pregnancy. British Journal of Cancer (2008) 98, I485- |493. doi:I0.1038/sj.bjc.660432I www.bjcancer.com Published online 8 April 2008

(c) 2008 Cancer Research UK

Keywords: breast cancer; tumour suppressors; epigenetic; mammary stem cell; genistein; soy

\section{GENISTEIN AND BREAST CANCER}

The assumption that high soy intake among Asian women explains their low breast cancer risk has led to numerous studies carried out in human populations and animal models. Human studies suggest that there indeed is a modest inverse association between high soy food consumption and reduced risk (Trock et al, 2006; Wu et al, 2008). However, several questions remain regarding a causative role of soy consumption in reducing breast cancer risk; the possibility that the association simply reflects other factors/ 'healthy' lifestyle affecting breast cancer risk cannot be excluded at the present time.

Many animal studies do not support an association between an exposure to this phytochemical during adulthood and reduced mammary tumorigenesis (Tables 1 and 2). The protective role of soy intake during adulthood is further questioned by the results obtained in an intervention study on premenopausal women showing that exposure to $100 \mathrm{mg}$ isoflavone (IF) supplement per day for 1 year did not reduce mammographic density (Maskarinec et al, 2003). Mammographic density is a biomarker of increased breast cancer risk; high density increases the risk by four- to sixfold. Further, the consumption of soy foods containing approximately $50 \mathrm{mg}$ IF per day for 2 years did not affect circulating steroid hormones or sex hormone-binding protein (Maskarinec et al, 2004), and thus the proposed reduction in breast cancer risk

\footnotetext{
*Correspondence: Dr L Hilakivi-Clarke; E-mail: clarkel@georgetown.edu Received 17 October 2007; revised 13 February 2008; accepted 3 March 2008; published online 8 April 2008
}

by soy cannot be explained through its effects on serum hormone levels in adults.

One possible explanation for the discrepancy between the protective role of soy found in two meta-analyses (Trock et al, 2006; Wu et al, 2008) and the lack of effect on biomarkers of breast cancer risk or the results generated in animal studies during adult exposure to soy/genistein is that, to be protective, this bioactive food component may need to be consumed during early life. In support of this argument, epidemiological studies indicate that childhood/adolescence exposure to soy provides protection against breast cancer later in life (Shu et al, 2001; Wu et al, 2002). Animal studies are in agreement with the findings obtained in humans, and we will briefly review the data on the effects of genistein/soy exposure in utero and/or during prepuberty on mammary tumorigenesis in animals. Studies carried out in rats and mice are discussed separately because the tumorigenesis models used in the two species are different.

\section{Rats}

Several studies have examined whether an exposure to genistein or soy protein isolate (SPI), either in utero or prepubertally, or a combination of both, affects later mammary tumorigenesis. In addition to genistin (the glucoside conjugate of genistein) and genistein (the aglycone), SPI contains daidzin (the glucoside conjugate) and daidzein (the aglycone), the other main IFs in soy. Daidzein has weaker oestrogenic properties than genistein and generally has not been considered responsible for the biological actions of soy. The third IF of SPI is glycitin and its aglycone glycitein, but they are present only at low levels. 
Table I Studies carried out in rats investigating the effects of early life genistein/SPI/soy exposure on mammary gland morphology and tumorigenesis

\begin{tabular}{|c|c|}
\hline $\begin{array}{l}\text { Exposure } \\
\text { time }\end{array}$ & $\begin{array}{l}\text { Compound/diet, dose, } \\
\text { route of administration }\end{array}$ \\
\hline \multicolumn{2}{|c|}{ In utero and perinatal exposure } \\
\hline GD $15-19$ & $\begin{array}{l}\text { Genistein } 1.5 \text { or } 30 \mathrm{mg} \mathrm{kg}^{-1} \\
\text { per day, s.c. }\end{array}$ \\
\hline GD $15-20$ & $\begin{array}{l}\text { Genistein } 20,100 \text {, or } 300 \mu \mathrm{g} \\
\text { per rat per day }(\sim 0.1,0.5 \\
\left.1.5 \mathrm{mg} \mathrm{kg} \mathrm{bw}^{-1}\right) \text {, s.c. }\end{array}$ \\
\hline GD $0-$ PND 0 & $\begin{array}{l}\text { Genistein 15, 150, or } 300 \text { p.p.m. in } \\
\text { AIN-93G diet (produces serum } \\
\text { levels corresponding to Asians on } \\
\text { high soy diet; Note I) }\end{array}$ \\
\hline GD $4-$ PND 0 & $\begin{array}{l}\text { Genistein } 250 \text { p.p.m. or SPI (gen } \\
216 \text { mg+daid } 160 \text { mg per kg) in } \\
\text { AIN-93G diet (Note I) }\end{array}$ \\
\hline
\end{tabular}

GD $0-21$

Genistein 250 p.p.m. in AIN-76A diet (Note I)

PND 2-8 Genistein $10 \mathrm{mg} \mathrm{kg} \mathrm{bw}^{-1}$ per day, s.c. (pharmacological dose; Note I)
Effect on mammary gland morphology

PND 28: no changes in TEB number

Not studied

PND 56: an increase in the number of TEBs, and a lobules in the highest genistein group Not studied

Not studied

PND 200: distended mammary glands with secretion and milk production, ductal hyperplasia, microcalcifications, fibrosis, and necrosis

In utero and pre/peripubertal exposure GD 0 - PND Genistein 25 or 250 p.p.m. in $21 \quad$ AIN-76A diet (250 p.p.m. produced serum levels of ca. 700 and $1800 \mathrm{pmol} \mathrm{ml}^{-1}$ on PND 7 and 21 , respectively)

GD I - PND Genistein 300 or 800 p.p.m. 22 in chow diet

GD 4 - PND 20\% SPI in AIN-93G diet 21, 33 or 50 (Note 2) decrease in the number of
PND 21 and 50: reduced number of TEBs. PND 50: lower number of lobules type I in the higher

genistein group

PND 22: increased ductal branching in the higher genistein group in males

PND 50: reduced number of TEBs

Not studied

Not studied
Effect on carcinogen-induced mammary tumour growth Reference

MNU (50 $\mathrm{mg} \mathrm{kg}^{-1}$ on PND 28): Pei et al (2003)

no changes in tumour latency and multiplicity by PND 182

DMBA ( $10 \mathrm{mg}$ per rat $\approx 50 \mathrm{mg} \mathrm{kg}^{-1}$ Hilakivi-Clarke et al (1999)

on PND 45-50): increased tumour

incidence. Follow-up until PND

170-200

DMBA ( $10 \mathrm{mg}$ per rat $\approx 50 \mathrm{mg} \mathrm{kg}^{-1}$ Hilakivi-Clarke et al (2002) on PND 47): no change in tumour latency, but increased tumour incidence on PND 119 in the high genistein group

MNU (50 $\mathrm{mg} \mathrm{kg}^{-1}$ on PND 5l): Su et al (2007a)

longer tumour latency in both

groups, and lower tumour

multiplicity and \% high-grade

tumours in SPI group on

PND 149

DMBA (80 $\mathrm{mg} \mathrm{kg}^{-1}$ on PND 50):

no effect on tumour multiplicity.

Follow-up until PND 230

Spontaneous: increased mammary Foster et al (2004)

atypical hyperplasias and in situ ductal

carcinomas of comedo type on

PND 200

DMBA (80 $\mathrm{mg} \mathrm{kg}^{-1}$ on PND 50):

a dose-dependent decrease in

tumour multiplicity by PND 230

You L, Sar M, Bartolucci EJ Mclntyre BS, Sriperumbudur R (2002) Modulation of mammary gland development in prepuberta male rats exposed to genistein and methoxychlor. Toxicol Sci 66 : 216-225

Rowlands JC, Hakkak R, Ronis MJ, Badger TM (2002) Altered mammary gland differentiation and progesterone receptor expression in rats fed soy and whey proteins. Toxicol Sci $\mathbf{7 0}$ : $40-45$

Not studied

MNU (50 $\mathrm{mg} \mathrm{kg}^{-1}$ on PND 5I): longer tumour latency, decreased tumour incidence and multiplicity by PND 149

DMBA $\left(80 \mathrm{mg} \mathrm{kg}^{-1}\right.$ on PND 50: longer tumour latency, and a decline in tumour incidence in the second generation. No difference in tumour multiplicity or volumes by PND 175

PND 50: increased lobular differentiation, but ductal and alveolar hyperplasia in the higher genistein groups
Su et al (2007a)

Hakkak et al (2000)

Delclos KB, Bucci TJ, Lomax LG, Latendresse JR, Warbritton A, Weis CC, Newbold RR (200I) Effects of dietary genistein exposure during development on male and female CD (Sprague-Dawley) rats. Reprod Toxicol 15: 647-663 
Early life genistein exposures in modifying breast cancer risk

Table I (Continued)

\begin{tabular}{|c|c|}
\hline $\begin{array}{l}\text { Exposure } \\
\text { time }\end{array}$ & $\begin{array}{l}\text { Compound/diet, dose, } \\
\text { route of administration }\end{array}$ \\
\hline \multicolumn{2}{|c|}{ Prepubertal exposure } \\
\hline PND $|-2|$ & $\begin{array}{l}\text { Genistein: } 250 \text { p.p.m. in } \\
\text { AIN-76A diet }\end{array}$ \\
\hline $\begin{array}{l}\text { PND 7, 10, 14, } \\
17,20\end{array}$ & $\begin{array}{l}\text { Genistein } 20 \mu \mathrm{g} \text { per pup per } \\
\text { day (ca.I } \mathrm{mg} \mathrm{kg} \mathrm{bw}^{-1} \text { ) s.c. }\end{array}$ \\
\hline PND 7-20 & $\begin{array}{l}\text { Genistein } 50 \mu \mathrm{g} \text { per pup per day } \\
\text { (ca.3.3-1.25 } \mathrm{mg} \mathrm{kg}^{-1} \text { per day) or }\end{array}$ \\
\hline
\end{tabular}

E2 $10 \mu \mathrm{g}$ per pup per day s.c.

PNDs 16, 18, Genistein $500 \mathrm{mg} \mathrm{kg}^{-1}$ per day 20 (in all studies) S.C.
Effect on mammary gland morphology

PND 50: reduced number of TEBs and increased number of lobules

PND 183: increased lobular differentiation
Effect on carcinogen-induced mammary tumour growth

Reference

DMBA (80 $\mathrm{mg} \mathrm{kg}^{-1}$ on PND 50): Lamartiniere et al (2002)

reduced tumour multiplicity by

PND 230

DMBA ( $10 \mathrm{mg}$ per rat $\approx 50 \mathrm{mg} \mathrm{kg}^{-1}$ Hilakivi-Clarke L, Onojafe I, on PND 45): reduced tumour Raygada M, Cho E, Skaar T, multiplicity and number of $\quad$ Russo I, Clarke R (1999) proliferating tumours on PND 171

Prepubertal exposure to zearalenone or genistein reduces mammary tumorigenesis. $\mathrm{Br} /$ Cancer $\mathbf{8 0}$ : $1682-1688$

PND 56: genistein reduced number of TEBs and epithelial density, increased number of lobuloalveolar structures

PND 50: reduced number of TEBs, increased number of lobules

DMBA (studied only in prepubertally $\mathrm{E}_{2}$-exposed rats: a significant decrease in tumour control rats)

DMBA (80 $\mathrm{mg} \mathrm{kg}^{-1}$ on PND 50): reduced mammary tumour multiplicity or incidence

Cabanes et al (2004)

Cotroneo MS, Wang J, Fritz WA, Eltoum IE, Lamartiniere CA (2002) Genistein action in the prepubertal
PND 15-19 Genistein 1.5 or $30 \mathrm{mg} \mathrm{kg} \mathrm{bw}^{-1}$ per day, s.c.

PND $23,25,27,29$
Genistein $50 \mathrm{mg} \mathrm{kg} \mathrm{bw}^{-1}$ per day, s.c.

Peripubertal exposure

PND 3I-45 Genistein 375 or 750 p.p.m. in diet incidence compared to
PND 28: no changes in TEB number

PND 30: increase in mammary gland size, and the number of lobules I, but no effect on the TEBs

PND 45: no effects on mammary ductal and lobuloalveolar development
MNU (50 $\mathrm{mg} \mathrm{kg}^{-1}$ on PND 28): decrease in tumour incidence through PND 182 (low-dose genistein)

Not studied

Not studied mammary gland in a chemoprevention model. Carcinogenesis 23: 1467-1474 Brown NM, Wang J, Cotroneo MS, Zhao YX, Lamartiniere CA (1998) Prepubertal genistein treatment modulates TGF-alpha, EGF and EGFreceptor $m R N A$ s and proteins in the rat mammary gland. Mol Cell Endocrinol I44: |49-165 Murrill WB, Brown NM, Zhang JX, Manzolillo PA, Barnes S, Lamartiniere CA (1996) Prepubertal genistein exposure suppresses mammary cancer and enhances gland differentiation in rats. Carcinogenesis I 7: | $45|-| 457$

Pei et al (2003)

Brown NM, Lamartiniere CA (1995) Xenoestrogens alter mammary gland differentiation and cell proliferation in the rat. Environ Health Perspect I03: $708-713$

Santell RC, Chang YC, Nair MG, Helferich WG (1997) Dietary genistein exerts estrogeneic effects upon the uterus, mammary gland and the hypothalamic/pityuitary axis in rats. J Nutr I27: 263-269

Not studied

DMBA $\left(80 \mathrm{mg} \mathrm{kg}^{-1}\right.$ on

Gallo et al (200I)

PND 50): longer tumour latency. No effect on the incidence, multiplicity, or median total tumour burden by PND 218

Not studied
MNU (50 $\mathrm{mg} \mathrm{kg}^{-1}$ on PND 50): no significant effects by PND 158
Kim H, Hall P, Smith M, Kirk M, Prasain JK, Barnes S, Grubbs C (2004) Chemoprevention by grape seed extract and genistein in carcinogen-induced mammary cancer in rats is diet dependent. J Nutr I 34: 3445S-3452S 
Table I (Continued)

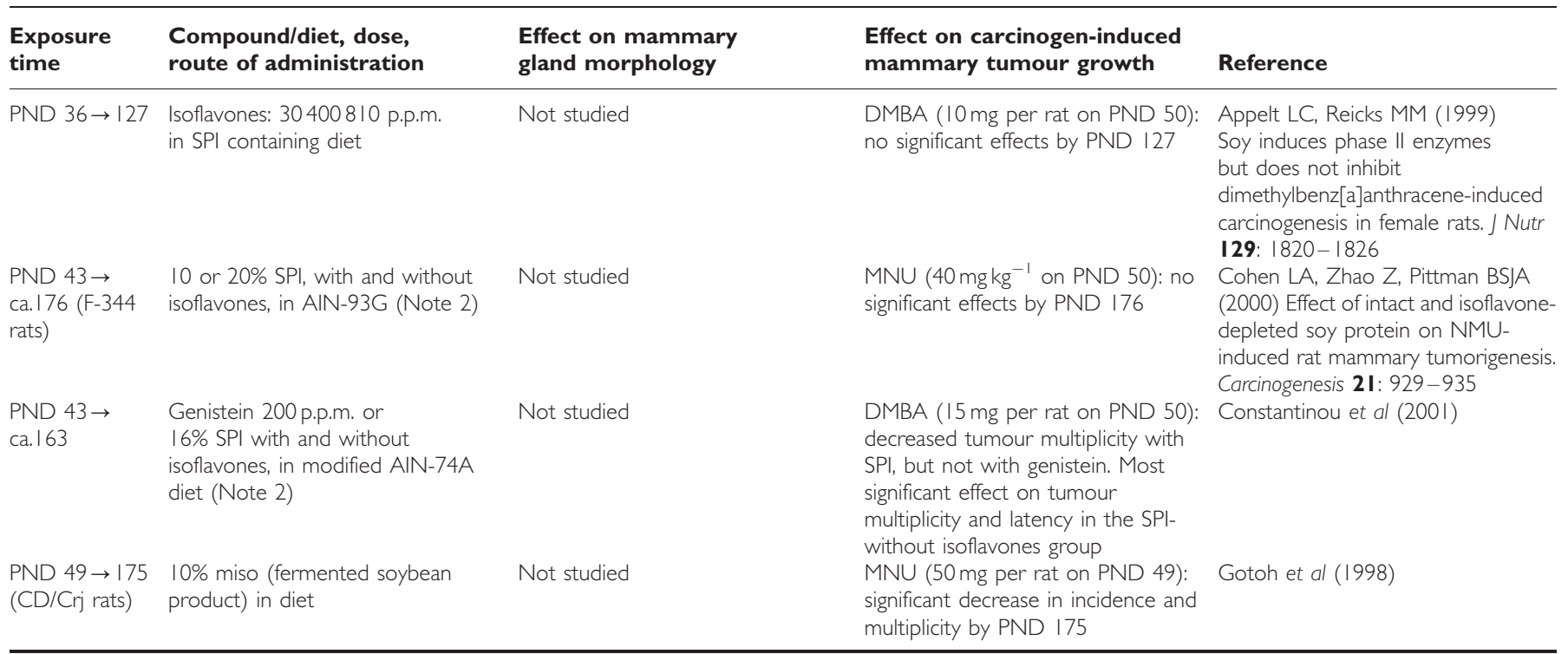

Abbreviations: bw = body weight; DMBA = dimethylbenz(a)anthracene; $G D=$ gestational day; $M N U=N$-methyl-n-nitrosourea; PND = postnatal day; p.p.m. = parts per million $(\mathrm{mg}$ per $\mathrm{kg}) ; \mathrm{SPI}=$ soy protein isolate; TEB = terminal end bud. Note I: Asian population on high soy diet consumes genistein ca. I - $30 \mathrm{mg}$ per day = ca. $0.02-0.55 \mathrm{mg} \mathrm{kg}^{-1}$ per day. Native Japanese adults are reported typically to consume 30-40 mg (aglycone units) of isoflavones per day (Wakai et al J Nutr 1998; 128: 209-213), their plasma levels being $~ 300 \mathrm{nmol}^{-1}$ (Adlercreutz et al Lancet 1993; 342: 1209-1210). Genistein intake in the Western Europe ca. $0.005 \mathrm{mg} \mathrm{kg}{ }^{-1}$ per day. For extrapolation from human to rodent, small animals need ca. 10 times higher concentrations compared to humans, since they are less susceptible to drugs (Wuttke et al Ageing Res Rev 2007; 6(2): I50-88). Thus, genistein doses $0.1-1.5 \mathrm{mg} \mathrm{kg}^{-1}$ per day to rodents would be comparable to average daily intake in Asian countries. Doses $>10 \mathrm{mg} \mathrm{kg}^{-1}$ per day are pharmacological. Note 2: SPI contains the isoflavones genistein $216 \mathrm{mg} \mathrm{kg}^{-1}$, and daidzein $160 \mathrm{mg} \mathrm{kg}^{-1}$, and their $\beta$-glycosides (Hakkak et al Cancer Epidemiol Biomarkers Prev 2000; 9: II3-I I7). SPI (I0 and 20\%) is estimated to contain ca. 50 and 100 times the intake of an average Japanese adult (Cohen et al Carcinogenesis 2000; 2I (5): $929-935)$. Note 3: SpragueDawley rats were used unless otherwise stated in the first column, under the 'exposure time'.

As shown in Table 1, the findings obtained in rats exposed to SPI or purified genistein during the fetal-perinatal period vary from study to study, with three studies reporting an increase in the incidence of either carcinogen-induced tumours (Hilakivi-Clarke et al, 1999; Hilakivi-Clarke et al, 2002) or spontaneous hyperplasias and ductal carcinomas in situ (Foster et al, 2004), one study reporting a reduction in tumour multiplicity and \% high grade tumours (Su et al, 2007a), and two studies reporting no effects (Lamartiniere et al, 2002; Pei et al, 2003). Two of these studies investigated the effects on mammary gland morphology in adult rats (Hilakivi-Clarke et al, 2002; Foster et al, 2004). In one study, genistein increased the number of terminal end buds (TEBs) (Hilakivi-Clarke et al, 2002), and the other study showed that genistein induced ductal hyperplasias (Foster et al, 2004). TEBs have at least two key functions: (1) they are located at the tips of growing ducts and lead the invasion of the epithelial tree to fill the mammary fat pad; (2) they are the sites where malignant transformation takes place (Hilakivi-Clarke, 2007). TEB number peaks after puberty onset at 1 month of age, and they disappear when the epithelial tree has filled the fat pad at 2 months of age. The corresponding structures in the human mammary gland are terminal ductal lobular units (Cardiff, 1998), of which 90\% of human breast cancers originate.

Studies examining whether an exposure to soy/SPI/genistein, which started at conception and continued until weaning, affects mammary tumorigenesis found a reduction in tumour multiplicity (Fritz et al, 1998; Table 1). Two groups have examined the effects of SPI exposure, which began during gestation and continued throughout adulthood on mammary tumorigenesis, reporting a reduction in mammary tumour incidence and/or multiplicity (Hakkak et al, 2000; Su et al, 2007a). Interestingly, the study by Hakkak et al (2000) found a decline in tumour incidence only in the second generation. The data regarding prepubertal exposure to genistein are very consistent in showing a reduction in mammary cancer risk. Table 1 indicates that all studies investigating an effect on mammary tumorigenesis report a reduction in risk in rats exposed to genistein via feed or through subcutaneous administration. The effects of genistein exposure on mammary gland morphology have been recently reviewed by Warri et al (2007), and they are consistent with the protective effect. All studies that investigated mammary gland morphology at the time the gland is most susceptible to malignant transformation indicate a reduction in the number of TEBs and an increase in lobular differentiation (Table 1).

A human parallel to the early life (neonatal) animal studies exists, infants exposed to soy formula. This exposure parallels an exposure during the first 3 weeks of life in rodents. However, at the present time, it is not known whether the high perinatal soy exposure among infant soy formula users has any effect on later breast cancer risk. The conclusions reached in reviews discussing the safety of infant soy formula suggest that it does not appear to cause adverse general health or reproductive outcomes or affect human growth (Strom et al, 2001). More cautious authors propose that the existing data are insufficient to draw definitive conclusions on safety and that the use of soy protein formulae should be limited only to those who cannot consume casein-based formulas (Turck, 2007).

Studies that have investigated whether lifetime exposure that begins at puberty has any effects have generated opposing findings (Table 1). Only one of the five studies that exposed rats to genistein or SPI found any effect on mammary tumour incidence or multiplicity (Constantinou et al, 2001), and two studies reported a longer tumour latency (Constantinou et al, 2001; Gallo et al, 2001). The study of Constantinou et al (2001) found that an exposure to SPI that was depleted of IFs had the most significant effect on tumour latency and multiplicity. Also, an exposure to $10 \%$ miso 
Early life genistein exposures in modifying breast cancer risk

Table 2 Studies carried out in mice investigating the effects of early life genistein/soy exposure on mammary gland morphology and tumorigenesis ${ }^{\mathrm{a}}$

\begin{tabular}{|c|c|c|c|c|}
\hline $\begin{array}{l}\text { Mouse strain, } \\
\text { exposure time }\end{array}$ & $\begin{array}{l}\text { Compound/diet, dose, route of } \\
\text { administration }\end{array}$ & $\begin{array}{l}\text { Effect on mammary gland } \\
\text { morphology }\end{array}$ & $\begin{array}{l}\text { Effect on oncogene- or } \\
\text { carcinogen-induced mammary } \\
\text { tumour growth }\end{array}$ & Reference \\
\hline \multicolumn{5}{|c|}{ In utero exposure (no studies) } \\
\hline \multicolumn{5}{|c|}{ In utero and prepubertal exposure } \\
\hline $\begin{array}{l}\text { FVB/N-TgN } \\
\text { (MMTV-neu), GD } \\
0-\text { PND } 21-23\end{array}$ & $\begin{array}{l}\text { 'Prevastein' containing (I) genistein } \\
6 \mathrm{mg}+\text { no daidzein, or (2) genistein } \\
28 \mathrm{mg}+\text { daidzein } 12 \mathrm{mg} \text {, or (3) genistein } \\
89 \mathrm{mg}+\text { daidzein } 42 \mathrm{mg} \text { per } \mathrm{kg} \\
\text { high fat diet }\end{array}$ & $\begin{array}{l}\text { PND 70: enhanced mammary gland } \\
\text { 'maturation' (decreased number of } \\
\text { TEBs) in the highest dose group }\end{array}$ & $\begin{array}{l}\text { No change in tumour onset. } \\
\text { Increase in tumour burden } \\
\text { (multiplicity and mass) in the medium } \\
\text { and high isoflavone groups. Follow-up } \\
\text { until PND I } 40\end{array}$ & $\begin{array}{l}\text { Luijten et al } \\
\text { (2004) }\end{array}$ \\
\hline \multicolumn{5}{|c|}{ Prepubertal exposure (no studies) } \\
\hline $\begin{array}{l}\text { Pre- or peripubertal } \\
\alpha \mathrm{ERKO} \text { and WT } \\
\text { mice }(\mathrm{C} 57 \mathrm{BI} / \\
6 \mathrm{I} \times \text { I29SVJ), PND } \\
2 \mathrm{I} \rightarrow \text { lifetime }\end{array}$ & $\begin{array}{l}\rightarrow \text { for lifetime exposure } \\
\text { Genistein } 1000 \text { p.p.m. in AIN-76A diet }\end{array}$ & Not studied & $\begin{array}{l}\text { MPA-DMBA }{ }^{\text {b}} \text { : no significant effects by } \\
\text { PND } 238\end{array}$ & $\begin{array}{l}\text { Day et al } \\
(2001)\end{array}$ \\
\hline $\begin{array}{l}\text { FVB/N-TgN } \\
\text { (MMTV/c-neu) } \\
\text { PND 25-196 }\end{array}$ & $\begin{array}{l}\text { Soy isoflavones (prevastein): I I, 39, I30 mg } \\
\text { per kg high fat (Western style) diet }\end{array}$ & $\begin{array}{l}\text { PND 70: increased mammary ductal } \\
\text { branching (all doses, PND 42) and } \\
\text { decreased number of TEBs in } \\
\text { the medium dose group }\end{array}$ & $\begin{array}{l}\text { No change in tumour incidence. } \\
\text { Increase in tumour multiplicity } \\
\text { and size (highest dose group) } \\
\text { by PND } 196\end{array}$ & $\begin{array}{l}\text { Thomsen et al } \\
\text { (2005) }\end{array}$ \\
\hline $\begin{array}{l}\text { TG.NK (MMTV/ } \\
\text { c-neu), PND } \\
28-210\end{array}$ & $\begin{array}{l}\text { Open formula (soy, alfaalfa, wheat, oat, } \\
\text { corn) NTP-2000 diet vs AIN-76A }\end{array}$ & Not studied & $\begin{array}{l}\text { Open formula diet significantly } \\
\text { decreased tumour incidence, } \\
\text { multiplicity and tumour } \\
\text { weight compared to AIN-76A } \\
\text { (follow-up until PND 210) }\end{array}$ & $\begin{array}{l}\text { Rao et al } \\
(1997)\end{array}$ \\
\hline $\begin{array}{l}\text { FVB/N-TgN } \\
(M M T V / c-n e u) \\
\text { PND } 28 \rightarrow \text { lifetime }\end{array}$ & $\begin{array}{l}\text { SPI including genistein I } 32 \text { mg+daidzein } \\
89 \text { mg per } \mathrm{kg} \text { high fat (Western style) diet }\end{array}$ & Not studied & No significant effects by PND 238 & $\begin{array}{l}\text { Luijten et al } \\
\text { (2004) }\end{array}$ \\
\hline $\begin{array}{l}\text { FVB/N-TgN } \\
(\mathrm{MMTV} / \mathrm{c}-\mathrm{neu}) \\
\text { starting on PND } \\
28-35 \rightarrow \text { lifetime }\end{array}$ & $\begin{array}{l}23.4 \% \text { soy meal, including genistein } \\
214 \text { p.p.m. and daidzein } \\
277 \text { p.p.m. in Purina } 500 \text { I diet }\end{array}$ & $\begin{array}{l}\text { PND 175: reduced mammary ductal } \\
\text { elongation and branching } \\
\text { (descriptive data). Potentiation of the } \\
\text { precocious differentiation by } E \text { of the } \\
\text { mammary gland (descriptive data) }\end{array}$ & $\begin{array}{l}\text { Longer tumour latency. (Necropsy on } \\
\text { PNDs 105, I40, 175, 224, } \\
266,315 \text {, and 420) }\end{array}$ & $\begin{array}{l}\text { Yang et al } \\
(2003)\end{array}$ \\
\hline $\begin{array}{l}\text { FVB/N-TgN } \\
(\mathrm{MMTV} / \mathrm{c}-\mathrm{neu}) \\
\text { starting on PND } \\
28-35 \rightarrow \text { lifetime }\end{array}$ & $\begin{array}{l}\text { Soy meal (Purina } 500 \mathrm{I} \text { ) diet including } \\
\text { genistein } 214 \mathrm{mg} \text { and daidzein } 277 \mathrm{mg} \text { per } \\
\mathrm{kg} \text { diet, or diet with pure genistein } 137 \mathrm{mg} \\
\text { and daidzein } 74 \mathrm{mg} \text { per } \mathrm{kg} \text { diet }\end{array}$ & Not studied & $\begin{array}{l}\text { Decrease in incidence in soy } \\
\text { meal group (follow-up } \\
\text { until PND 420) }\end{array}$ & Liu et al (2005) \\
\hline $\begin{array}{l}\text { FVB/N-TgN } \\
(\mathrm{MMTV} / \mathrm{c}-\mathrm{neu}) \\
\text { starting on PND } \\
42-49 \rightarrow \text { lifetime }\end{array}$ & $\begin{array}{l}\text { Genistein: } 250 \mathrm{mg} \text {, or NovaSoy with } \\
\text { genistein } 250 \mathrm{mg} \text { per } \mathrm{kg} \text { AIN-93G+the } \\
\text { mice were mated and allowed one full- } \\
\text { term pregnancy and } 2 \text { weeks of lactation } \\
\text { during the first } 3 \text { month of life }\end{array}$ & Not studied & $\begin{array}{l}\text { Longer tumour latency by both genistein } \\
\text { and NovaSoy. No changes in tumour } \\
\text { incidence or multiplicity by PND } 238\end{array}$ & $\begin{array}{l}\text { Jin and } \\
\text { MacDonald } \\
(2002)\end{array}$ \\
\hline
\end{tabular}

Abbreviations: DMBA = dimethylbenz(a)anthracene; GD = gestational day; MPA = medroxyprogesterone acetate; $M N U=N$-methyl-n-nitrosourea; $P N D=$ postnatal day; $\mathrm{SPI}=$ soy protein isolate; TEB = terminal end bud. ${ }^{\mathrm{a}}$ Tumour models: spontaneous mammary tumour model of transgenic mice (MMTV/c-neu), and a DMBA-induced, MPAprimed mouse mammary tumour model (MPA-DMBA). bMedroxyprogesterone acetate - priming with $2 \times 20 \mathrm{mg}$ pellets on week 7 , DMBA I mg single dose orally on weeks 9 , 10,12 , and 13 .

was reported to reduce mammary tumorigenesis in rats (Gotoh et al, 1998).

To summarise, genistein/SPI exposure limited to the prepubertal period appears to reduce later mammary cancer risk in rats, but the effect is mostly lost if the exposure remains high throughout adult life. It is noteworthy, however, that the genistein/SPI formulations and routes of administration in different studies varied (injected $v s$ in the diet), which makes it difficult to draw definitive conclusions by comparing results of these studies. However, although genistein/SPI exposure in utero may increase susceptibility to malignant transformation, if the exposure continues to adulthood a reduction in risk may occur. The latter is consistent with low breast cancer risk among Asian women who are exposed to soy throughout their lifetime, suggesting that in utero exposure primes the gland for later protective effects of genistein. Why a similar reduction in risk is not seen in rats in which exposure started postnatally and continued through the rest of the study is not clear.

\section{Mice}

Studies on the effects of genistein/soy on mammary tumorigenesis in mouse models are scarce, and all studies but one have used a transgenic mouse model in which tumours are caused by an oncogene expressed in the mammary gland during embryogenesis (Table 2). Further, the mouse studies are more diverse than the rat studies concerning the age when the mammary gland morphology was studied. The findings obtained in these studies show that mice exposed to genistein during fetal development exhibit an increase in the number of TEBs as adults (reviewed by Warri et al, 2007). According to different studies, neonatal and/or pubertal genistein/ SPI exposure either increases (Luijten et al, 2004; Thomsen et al, 2005) or reduces (Yang et al, 2003) epithelial differentiation.

No studies have examined the effects of exposures to genistein/ soy that were limited to the fetal or prepubertal period on mammary tumorigenesis. Only one study in mice has investigated whether an exposure from conception until puberty to soy IFs 
affects mammary tumorigenesis (Table 2; Luijten et al, 2004). The study found that Prevastein ${ }^{\mathbb{B}}$, an IF concentrate, not only increased mammary tumour multiplicity and burden but also accelerated mammary gland development (Luijten et al, 2004). This observation is opposite to the findings obtained in rats showing that an exposure from conception to weaning is protective against carcinogen-induced mammary tumours.

There are a total of seven studies carried out in mice that were fed SPI or soy meal from the prepubertal period onwards, until the tumour monitoring was completed (Table 2). The studies reported that the exposure reduced (Rao et al, 1997; Liu et al, 2005), increased (Thomsen et al, 2006), or had no effect (Day et al, 2001; Jin and MacDonald, 2002; Luijten et al, 2004) on mammary tumour incidence and/or multiplicity and size. In addition, a delayed tumour onset after genistein or soy exposure was reported in two of the six genetically modified mouse studies (Jin and MacDonald, 2002; Yang et al, 2003). Thus, the data obtained through studies carried out in mice conflict with each other, and it is not clear whether the diversity in outcome can be explained by differences in the route of administration, doses used, or the type of exposure (genistein $v s$ SPI $v s$ soy meal). Furthermore, studies carried out using rats and mice differ by the model systems used (carcinogen-induced in rats or oncogene-driven in mice) and the differences in mammary gland morphology and oestrogen responsiveness of the established tumours (responsive in rats or non-responsive in mice), which can explain why the data generated in the rat and mouse studies are diverse. Whether these findings can be explained by the oestrogenicity of genistein remains to be investigated.

\section{MECHANISMS}

Two types of changes in the mammary glands of individuals exposed to genistein early in life may mediate the effects on later cancer risk: alterations in gene expression and morphological changes. It is most likely that both are involved and that they interact with each other; that is, changes in gene expression affect morphology and vice versa. In addition, it is possible that the better bioavailability of IFs in children, compared to adults (Halm et al, 2007), affects the findings.

As discussed above, the effects of early life genistein exposures on mammary gland morphology and the developmental stage, when animals were examined, vary from study to study, making it difficult to tie the changes in the morphology to observed or anticipated changes in mammary tumorigenesis. An exception is prepubertal exposure to genistein: all the studies carried out, showing a reduction in mammary tumorigenesis in rats, also report consistent changes in mammary gland morphology. This exposure induces differentiation of the mammary epithelium by eliminating TEBs and increasing the number of differentiated lobular-alveolar structures (Table 1). These morphological changes may be initiated by genistein-induced alterations in the mammary stem cell number and/or fate. Of the various epithelial structures, TEBs are believed to contain the highest number of mammary stem cells (Woodward et al, 2005).

\section{Stem cells}

During mammary gland development, many stem and progenitor cells gradually commit to differentiation pathways, but some remain uncommitted or partly differentiated within the mammary tissue (Smalley and Ashworth, 2003). Both the stem cell number and their fate may be determined during critical windows of mammary gland development; that is, during in utero period, puberty, and pregnancy. The hormonal environment associated with these stages might affect breast cancer risk by increasing or reducing the total number of replicating stem cells, their lineagespecific differentiation to myoepithelial and luminal cells, and eventually the number of cells at risk for malignant transformation (Trichopoulos et al, 2005). There is accumulating evidence for the hypothesis that breast cancer risk is determined in part by the number of susceptible breast stem/progenitor cells that can serve as targets for transformation (Liu et al, 2008).

Stem cells have been linked to pregnancy-induced dual effects on breast cancer risk. Although pregnancy, pregnancy hormonal environment, and soy exposures during pregnancy in affecting mother's risk are not discussed in this review, the mechanisms by which pregnancy alters susceptibility to develop breast cancer may be relevant in explaining the protective effects of prepubertal genistein and oestrogen exposures. We (Cabanes et al, 2004) and others have shown that peripubertal oestrogen exposure reduces mammary gland tumorigenesis in animal models. According to Sivaraman et al (1998), pregnancy hormones induce a molecular switch in mammary stem cells that inhibits cell proliferation in response to subsequent exposure to hormones or carcinogens. Wagner and Smith (2005) have identified cells in the mammary gland that are likely to represent pregnancy-related epithelial cells (PI-MECs) with stem cell characteristics. These investigators have suggested that the PI-MECs, which do not undergo apoptosis during postlactational remodelling and thus persist the rest of the (mouse's) life after the first pregnancy-lactation cycle, could be the mediators of the long-term pregnancy-related protective effects against breast cancer (Wagner and Smith, 2005). However, in a transgenic mouse model prone to pregnancy-related mammary tumorigenesis (MMTV-neu mice), the PI-MECs may be the targets for neoplastic transformation (Wagner and Smith, 2005), underlining the complexity of mammary stem cells and their role in malignant transformation. Several excellent papers have been published regarding the effects of pregnancy on gene expression, and clearly some of the changes induced by pregnancy and pubertal genistein exposure are similar, such as upregulation of BRCA1 and p53 (Cabanes et al, 2004; de Assis and Hilakivi-Clarke, 2006).

\section{Changes in cell proliferation and apoptosis}

If an early life exposure to genistein, or other oestrogenic compounds, alters breast cancer risk by targeting epithelial stem or progenitor cells, changes in cell proliferation and apoptosis are expected to be seen. For example, a higher number of stem cells in individuals exposed to oestrogenic compounds in utero, or to diets that increase later mammary cancer risk, might be associated with increased cell proliferation, either by inducing proliferation or by reflecting a need for stem cells to fullfil the demand of increasing the number of luminal and myoepithelial mammary cells to form TEBs, lobules and ducts. An illustrative example is caveolin-1 knockout mice, which exhibit dysregulation of mammary stem cell self-renewal, probably due to increased $\mathrm{Wnt} / \beta$-catenin signalling (Sotgia et al, 2005).

Fetal exposure to genistein has been reported to increase mitotic activity in the mammary gland (Foster et al, 2004), which is consistent with the findings linking this exposure to increased risk of developing mammary tumours. The effects of prepubertal genistein exposure on cell proliferation in rats are also consistent with the effects on tumorigenesis. When determined using the heavy water labelling method (Kim et al, 2007) or by labelling the cells with Brdu (Pei et al, 2003), exposure to genistein in the prepubertal period inhibited mammary epithelial cell proliferation. If the genistein exposure continues to adulthood, it may impact neither cell proliferation nor apoptosis (Gallo et al, 2002), again in agreement with the findings regarding the effects on mammary tumorigenesis. 


\section{Changes in gene expression}

The means by which hormonal changes would affect stem cells might be due to changes in gene expression. As an attempt to define the key changes in mammary reprogramming by hormones, an extensive list of genes attributed to mammary stem cells has been presented (Woodward et al, 2005). To summarise, stem cell fate, that is self-renewal and differentiation along specific lineage pathways, is regulated by multiple factors. In the mammary gland, Wnt/ $\beta$-catenin, Notch and Hedgehog signalling pathways impact mammary stem/progenitor cell fate. BRCA1 (Sotgia et al, 2005) and phosphatase and tensin homologue deleted on chromosome 10 (PTEN) (Stiles et al, 2004) may also be involved. In particular, BRCA1 is suggested to play a critical role in the differentiation of oestrogen receptor (ER)-negative stem/progenitor cells to ER-positive luminal cells (Liu et al, 2008). As discussed below, genistein affects the expression of some of the genes that regulate mammary stem cell fate.

Many of these changes in gene expression induced by genistein reflect the chemical structure of this phytochemical and thus the activation of the ERs, but some are due to genistein's ability to inhibit several protein kinases. Interestingly, the effects of genistein on the ER expression are variable between different studies, with some reporting a reduction (Pei et al, 2003) and some an increase in the ER- $\alpha$ levels (Su et al, 2007a). Studies are relatively consistent in showing an upregulation of ER- $\beta$ by genistein. Oestrogen receptors may be linked to stem cells, although it is not clear whether mammary stem cells express or do not express this receptor.

It is difficult to determine the importance of the genes identified in microarray studies in human breast cancer cells in mediating the preventive effects of genistein, as the changes may not have a direct impact on altering the susceptibility to mammary tumorigenesis. A recent microarray study, which used the mammary glands of adult rats exposed to genistein via diet from conception onwards, identified several genes that relate to stem cell fate and/or regulate mammary cell proliferation, apoptosis and differentiation, including increased expression of Sfrp2 (Wnt receptor) and Hes1 (Notch signalling pathway), and reduced expression of Wnt5a and Notch2 (Su et al, 2007b). Since this exposure was also reported to lengthen tumour latency and reduce tumour incidence and multiplicity (Su et al, 2007a), it is possible that genistein/SPI reduces mammary cancer risk by affecting stem cell fate.

\section{GENISTEIN AND TUMOUR SUPPRESSOR GENES}

It is clear that no single genetic change is responsible for the initiation of all breast cancers, but this disease can have a highly varying genetic background. Alterations in the expression of tumour suppressor genes, either by mutations or directly/ indirectly due to epigenetic changes, are particularly critical in affecting breast cancer risk. We will briefly review two tumour suppressor genes whose expression is altered in animals exposed to genistein: they are BRCA1 and PTEN.

\section{BRCA1}

Hereditary mutations in BRCA1 not only increase the risk of breast cancer but also risk for ovarian and prostate cancer. Women who have inherited mutations in the BRCA1 tumour suppressor gene have an approximately $66 \%$ likelihood of developing breast cancer by the age of 70 (Friedenreich et al, 2001). In sporadic breast cancers, BRCA1 mutations are rare; however, $30-40 \%$ of sporadic cancers show reduced expression of BRCA1 (see Ashworth, 2004).

BRCA1 has many biological functions. This protein interacts with RAD51 protein (Ashworth, 2004) and, as a result, BRCA1 is capable of acting as a gatekeeper in maintaining genomic integrity by preventing DNA damage and inducing DNA repair. The C terminus of BRCA1 interacts with several transcription factors and thus can regulate basal transcriptional machinery. The importance of BRCA1 for normal mammary development has been demonstrated through a transgenic mouse model, this model expresses a splice variant of BRCA1, which lacks the N-terminal RING finger domain (MMTV-BRCA1sv) (Hoshino et al, 2007). The Brcal mutant mice exhibited enhanced TEB proliferation at puberty and marked mammary lobulo-alveolar development, and they had an increased tumorigenesis and accelerated mortality after a challenge by DMBA.

Several findings indicate a link between genistein and BRCA1, although most of the studies focus either on genistein's direct effects on BRCA1 (in vitro) or its effects on BRCA1 in adult animals. In vitro studies have shown that physiological doses of genistein $(0.5-1.0 \mu \mathrm{M})$ upregulate BRCA1 in ER + human breast cancer cells and in prostate cancer cells (Fan et al, 2006). In addition, genistein upregulates the expression of both Brcal and Brca2 mRNA in adult ovariectomised rats (Vissac-Sabatier et al, 2003). However, the findings obtained in mice inoculated with mammary tumour cells obtained from conditional Brcal-/- mice, showing that dietary exposure to 750 p.p.m. genistein reduced the size of the tumours by $50 \%$, indicate that genistein can be protective in the absence of functional Brcal (Tominaga et al, 2007). The potential protective effect of pubertal genistein exposure may be linked to an upregulation of Brcal: we noted that this tumour suppressor is upregulated in the mammary glands of rats exposed daily to $50 \mu \mathrm{g}$ genistein or $10 \mu \mathrm{g}$ E2 during prepuberty (Cabanes et al, 2004). Ongoing studies in our laboratory are determining whether prepubertal exposure to 500 p.p.m. genistein affects mammary tumorigenesis in heterozygous Brca1 +/- mice.

\section{Phosphatase and tensin homologue deleted on chromosome 10 (PTEN)}

Inactivating mutations or deletions of the PTEN gene are among the most common changes found in human cancers, particularly in prostate and endometrial cancers (Blanco-Aparicio et al, 2007). Downregulation in PTEN expression or signalling has also been identified in several other types of cancers, including inherited and sporadic breast cancers. The PTEN protein is a lipid phosphatase and has been suggested to act as a tumour suppressor owing to its inhibition of the PI3K/Akt signalling pathway. A recent microarray analysis, comparing endometrial tissues obtained from Pten $+1-$ and wild-type mice, identified ER and its downstream targets as genes that might be linked to the increased endometrial cancer risk (Lian et al, 2006). Interestingly, PTEN may be one of the key genes BRCA1 has to repair to prevent malignant transformation: frequent gross PTEN mutations, involving intragenic chromosome breaks, inversions, deletions and microcopy number aberrations are found in BRCA1-deficient tumours (Saal et al, 2008).

A study carried out utilising rats found that genistein promotes apoptosis in mammary epithelial cells by inducing PTEN (Dave et al, 2005). These changes were accompanied by a decrease in mammary tumorigenesis. Fetal exposure to genistein or SPI at doses that had no effect on mammary tumorigenesis did not affect Pten protein expression or apoptosis in the TEBs of adult rats (Su et al, 2007a). However, if the exposure to genistein or SPI continued throughout the postnatal life, PTEN immunostaining and apoptosis were increased in the mammary TEBs (Dave et al, 2005).

\section{EPIGENETICS}

The mechanisms responsible for persistent changes in gene expression in the mammary glands of individuals exposed to genistein or other (oestrogenic) compounds early in life are most 
likely to involve epigenetic modifications. In contrast to mutations or other events that cause alterations in the DNA sequence, epigenetic changes cause alterations in gene transcription; that is they determine whether a gene is expressed or not. Two of the best characterised means of epigenetic modifications are DNA methylation and histone modifications (Tang and Ho, 2007). Epigenetics is now known to be the key process during early development that allows the environment to interact with the genotype, resulting in the observed phenotype. Thus, early life dietary exposures may modify later breast cancer risk through epigenetic changes that alter the pathways that participate in regulating mammary gland development.

Genistein has been reported to affect DNA methylation (Dolinoy et al, 2006). Methylation prevents gene expression, while demethylation leads to increased expression of previously methylated genes. Interestingly, genistein might both methylate and demethylate genes. The evidence that genistein induces methylation comes from studies showing that maternal exposure to genistein increases methylation of six cytosine-guanine sites at the viable yellow Agouti mice (Dolinoy et al, 2006), increasing the number of Agouti offspring that exhibit pseudoagouti phenotype, which in turn is linked to lowered cancer risk. However, genistein inhibits DNA methyltransferases (Day et al, 2002), which catalyse the addition of a methyl group, causing demethylation of the CpG islands. It is not known whether prepubertal genistein exposure might increase or reduce methylation patterns.

\section{CONCLUSIONS}

The evidence obtained both in epidemiological (Shu et al, 2001; $\mathrm{Wu}$ et al, 2002) and animal studies (Tables 1 and 2) suggests that genistein/soy exposure during the period preceding puberty reduces later susceptibility to develop breast cancer. Further, if the exposure occurs during the fetal period, no protection may be seen, but if it continues from conception onwards, genistein/soy may be protective. At the present time, no convincing explanation can be offered as to why the breast cancer risk-reducing effect of genistein/soy might be strongest during childhood and early adolescence. One possibility is that it is linked to increased differentiation of the mammary gland and elimination of targets that are the sites of malignant transformation (i.e., TEBs and mammary stem/progenitor cells). Thus, early genistein/soy exposure might have similar effects on the mammary gland than early pregnancy does. It is well established that early first pregnancy (before 20 years of age) reduces breast cancer risk, while women undergoing their first pregnancy after age 35 are at an increased risk.

The reduction in breast cancer risk induced by early genistein/ soy exposure is also likely to reflect changes in the expression of multiple genes. For example, in animal models, prepubertal exposure to genistein causes a persistent upregulation of Brcal (Cabanes et al, 2004) and it might upregulate PTEN (Dave et al, 2005). It is not known whether all these changes (or none of them) lead to a reduction in mammary cancer risk. The complexity between genistein/soy, the genes it activates/inhibits, and breast cancer risk are also illustrated by the fact that genistein activates ER- $\alpha$, which in turn interacts with BRCA1 (Fan et al, 2006) and PTEN (Lian et al, 2006). The causality between the changes in gene expression induced by genistein/soy intake and altered breast cancer risk can be addressed at least partly by using genetically modified mouse models such as Brcal or Pten knockout mice.

\section{ACKNOWLEDGEMENTS}

This work was supported by grants from NCI U54 CA0010097*0 (LHC and SM), NIEHS R21ES13858-3 (LHC) and the Academy of Finland (NMS).

\section{REFERENCES}

Ashworth A (2004) Refocusing on BRCA1. Nat Cell Biol 6: 916-917

Blanco-Aparicio C, Renner O, Leal JF, Carnero A (2007) PTEN, more than the AKT pathway. Carcinogenesis 28: 1379-1386

Cabanes A, Wang M, Olivo S, de Assis S, Gustafsson JA, Khan G, Hilakivi-Clarke L (2004) Prepubertal estradiol and genistein exposures up-regulate BRCA1 mRNA and reduce mammary tumorigenesis. Carcinogenesis 25: $741-748$

Cardiff RD (1998) Are the TDLU of the human the same as the LA of mice? J Mammary Gland Biol Neoplasia 3: 3-5

Constantinou AI, Lantvit D, Hawthorne M, Xu X, van Breemen RB, Pezzuto JM (2001) Chemopreventive effects of soy protein and purified soy isoflavones on DMBA-induced mammary tumors in female Sprague-Dawley rats. Nutr Cancer 41: 75-81

Dave B, Eason RR, Till SR, Geng Y, Velarde MC, Badger TM, Simmen RC (2005) The soy isoflavone genistein promotes apoptosis in mammary epithelial cells by inducing the tumor suppressor PTEN. Carcinogenesis 26: $1793-1803$

Day JK, Bauer AM, DesBordes C, Zhuang Y, Kim BE, Newton LG, Nehra V, Forsee KM, MacDonald RS, Besch-Williford C, Huang TH, Lubahn DB (2002) Genistein alters methylation patterns in mice. J Nutr 132: 2419S-2423S

Day JK, Besch-Williford C, McMann TR, Hufford MG, Lubahn DB, MacDonald RS (2001) Dietary genistein increased DMBA-induced mammary adenocarcinoma in wild-type, but not ER alpha KO, mice. Nutr Cancer 39: 226-232

de Assis S, Hilakivi-Clarke L (2006) Timing of dietary estrogenic exposures and breast cancer risk. Ann NY Acad Sci 1089: 14-35

Dolinoy DC, Weidman JR, Waterland RA, Jirtle RL (2006) Maternal genistein alters coat color and protects avy mouse offspring from obesity by modifying the fetal epigenome. Environ Health Perspect 114: $567-572$
Fan S, Meng Q, Auborn K, Carter T, Rosen EM (2006) BRCA1 and BRCA2 as molecular targets for phytochemicals indole-3-carbinol and genistein in breast and prostate cancer cells. Br J Cancer 94: $407-426$

Foster WG, Younglai EV, Boutross-Tadross O, Hughes CL, Wade MG (2004) Mammary gland morphology in Sprague-Dawley rats following treatment with an organochlorine mixture in utero and neonatal genistein. Toxicol Sci 77: $91-100$

Friedenreich CM, Courneya KS, Bryant HE (2001) Influence of physical activity in different age and life periods on the risk of breast cancer. Edidemiology 12: 604-612

Fritz WA, Coward L, Wang J, Lamartiniere CA (1998) Dietary genistein: perinatal mammary cancer prevention, bioavailability and toxicity testing in the rat. Carcinogenesis 19: $2151-2158$

Gallo D, Ferrandina G, Giacomelli S, Fruscella E, Zannoni G, Morazzoni P, Riva A, Bombardelli E, Mancuso S, Scambia G (2002) Dietary soy modulation of biochemical parameters in DMBA-induced mammary tumors. Cancer Lett 186: $43-48$

Gallo D, Giacomelli S, Cantelmo F, Zannoni GF, Ferrandina G, Fruscella E, Riva A, Morazzoni P, Bombardelli E, Mancuso S, Scambia G (2001) Chemoprevention of DMBA-induced mammary cancer in rats by dietary soy. Breast Cancer Res Treat 69: 153-164

Gotoh T, Yamada K, Yin H, Ito A, Kataoka T, Dohi K (1998) Chemoprevention of $\mathrm{N}$-nitroso- $\mathrm{N}$-methylurea-induced rat mammary carcinogenesis by soy foods or biochanin A. Jpn J Cancer Res 89: $137-142$

Hakkak R, Korourian S, Shelnutt SR, Lensing S, Ronis MJ, Badger TM (2000) Diets containing whey proteins or soy protein isolate protect against 7,12-dimethylbenz(a)anthracene-induced mammary tumors in female rats. Cancer Epidemiol Biomarkers Prev 9: 113-117 
Halm BM, Ashburn LA, Franke AA (2007) Isoflavones from soya foods are more bioavailable in children than adults. Br J Nutr 98: 998-1005

Hilakivi-Clarke L (2007) Nutritional modulation of terminal end buds: its relevance to breast cancer prevention. Curr Cancer Drug Targets 7: $465-474$

Hilakivi-Clarke L, Cho E, Cabanes A, DeAssis S, Olivo S, Helferich W, Lippman ME, Clarke R (2002) Dietary modulation of pregnancy estrogen levels and breast cancer risk among female rat offspring. Clin Cancer Res 8: $3601-3610$

Hilakivi-Clarke L, Cho E, Onojafe I, Raygada M, Clarke R (1999) Maternal exposure to genistein during pregnancy increases carcinogen-induced mammary tumorigenesis in female rat offspring. Oncol Rep 6: 1089-1095

Hoshino A, Yee CJ, Campbell M, Woltjer RL, Townsend RL, van der MR, Shyr Y, Holt JT, Moses HL, Jensen RA (2007) Effects of BRCA1 transgene expression on murine mammary gland development and mutageninduced mammary neoplasia. Int J Biol Sci 3: $281-291$

Jin Z, MacDonald RS (2002) Soy isoflavones increase latency of spontaneous mammary tumors in mice. J Nutr 132: 3186-3190

Kim HA, Jeong KS, Park DH, Lee JA, Jeong WI, Kim YK (2007) Heavy water labeling method for measuring the effect of genistein on mammary gland carcinogenesis. Mol Cell Biochem 301: 201-208

Lamartiniere CA, Cotroneo MS, Fritz WA, Wang J, Mentor-Marcel R, Elgavish A (2002) Genistein chemoprevention: timing and mechanisms of action in murine mammary and prostate. J Nutr 132: $552 \mathrm{~S}-558 \mathrm{~S}$

Lian Z, De LP, Di CA (2006) Gene expression analysis reveals a signature of estrogen receptor activation upon loss of Pten in a mouse model of endometrial cancer. J Cell Physiol 208: 255-266

Liu B, Edgerton S, Yang X, Kim A, Ordonez-Ercan D, Mason T, Alvarez K, McKimmey C, Liu N, Thor A (2005) Low-dose dietary phytoestrogen abrogates tamoxifen-associated mammary tumor prevention. Cancer Res 65: $879-886$

Liu S, Ginestier C, Charafe-Jauffret E, Foco H, Kleer CG, Merajver SD, Dontu G, Wicha MS (2008) BRCA1 regulates human mammary stem/ progenitor cell fate. Proc Natl Acad Sci USA 105(5): 1680 - 1685

Luijten M, Thomsen AR, van den Berg JA, Wester PW, Verhoef A, Nagelkerke NJ, Adlercreutz H, van Kranen HJ, Piersma AH, Sorensen IK, Rao GN, van Kreijl CF (2004) Effects of soy-derived isoflavones and a high-fat diet on spontaneous mammary tumor development in Tg.NK (MMTV/c-neu) mice. Nutr Cancer 50: 46-54

Maskarinec G, Franke AA, Williams AE, Hebshi S, Oshiro C, Murphy S, Stanczyk FZ (2004) Effects of a 2-year randomized soy intervention on sex hormone levels in premenopausal women. Cancer Epidemio Biomarkers Prev 13: 1736 - 1744

Maskarinec G, Williams AE, Carlin L (2003) Mammographic densities in a one-year isoflavone intervention. Eur J Cancer Prev 12: 165-169

Pei RJ, Sato M, Yuri T, Danbara N, Nikaido Y, Tsubura A (2003) Effect of prenatal and prepubertal genistein exposure on $N$-methyl- $N$-nitrosoureainduced mammary tumorigenesis in female Sprague-Dawley rats. In Vivo 17: 349 - 357

Rao GN, Ney E, Herbert RA (1997) Influence of diet on mammary cancer in transgenic mice bearing an oncogene expressed in mammary tissue. Breast Cancer Res Treat 45: 149-158

Saal LH, Gruvberger-Saal SK, Persson C, Lovgren K, Jumppanen M, Staaf J, Jonsson G, Pires MM, Maurer M, Holm K, Koujak S, Subramaniyam S, Vallon-Christersson J, Olsson H, Su T, Memeo L, Ludwig T, Ethier SP, Krogh M, Szabolcs M, Murty VV, Isola J, Hibshoosh H, Parsons R, Borg A (2008) Recurrent gross mutations of the PTEN tumor suppressor gene in breast cancers with deficient DSB repair. Nat Genet 40: 102-107 Shu XO, Jin F, Dai Q, Wen W, Potter JD, Kushi LH, Ruan Z, Gao YT, Zheng W (2001) Soyfood intake during adolescence and subsequent risk of breast cancer among Chinese women. Cancer Epidemiol Biomarkers Prev 10: $483-488$

Sivaraman L, Stephens LC, Markaverich BM, Clark JA, Krnacik S, Conneely OM, O'Malley BW, Medina D (1998) Hormone-induced refractoriness to mammary carcinogenesis in Wistar-Furth rats. Carcinogenesis 19: $1573-1581$

Smalley M, Ashworth A (2003) Stem cells and breast cancer: A field in transit. Nat Rev Cancer 3: $832-844$

Sotgia F, Williams TM, Cohen AW, Minetti C, Pestell RG, Lisanti MP (2005) Caveolin-1-Deficient Mice Have An Increased Mammary Stem Cell Population with Upregulation of Wnt/beta-Catenin Signaling. Cell Cycle 4(12): $1808-1816$

Stiles B, Groszer M, Wang S, Jiao J, Wu H (2004) PTENless means more. Dev Biol 273: 175 - 184

Strom BL, Schinnar R, Ziegler EE, Barnhart KT, Sammel MD, Macones GA Stallings VA, Drulis JM, Nelson SE, Hanson SA (2001) Exposure to soy-based formula in infancy and endocrinological and reproductive outcomes in young adulthood. JAMA 286: 807 -814

Su Y, Eason RR, Geng Y, Till SR, Badger TM, Simmen RC (2007a) In utero exposure to maternal diets containing soy protein isolate, but not genistein alone, protects young adult rat offspring from NMU-induced mammary tumorigenesis. Carcinogenesis 28: 1046-1051

Su Y, Simmen FA, Xiao R, Simmen RC (2007b) Expression profiling of rat mammary epithelial cells reveals candidate signaling pathways in dietary protection from mammary tumors. Physiol Genomics 30: 8-16

Tang WY, Ho SM (2007) Epigenetic reprogramming and imprinting in origins of disease. Rev Endocr Metab Disord 8: 173-182

Thomsen AR, Almstrup K, Nielsen JE, Sorensen IK, Petersen OW, Leffers H, Breinholt VM (2006) Estrogenic effect of soy isoflavones on mammary gland morphogenesis and gene expression profile. Toxicol Sci 93: $357-368$

Thomsen AR, Mortensen A, Breinholt VM, Lindecrona RH, Penalvo JL Sorensen IK (2005) Influence of Prevastein, an isoflavone-rich soy product, on mammary gland development and tumorigenesis in Tg.NK (MMTV/c-neu) mice. Nutr Cancer 52: 176-188

Tominaga Y, Wang A, Wang RH, Wang X, Cao L, Deng CX (2007) Genistein inhibits Brcal mutant tumor growth through activation of DNA damage checkpoints, cell cycle arrest, and mitotic catastrophe. Cell Death Differ 14: $472-479$

Trichopoulos D, Lagiou P, Adami HO (2005) Towards an integrated model for breast cancer etiology: the crucial role of the number of mammary tissue-specific stem cells. Breast Cancer Res 7: 13-17

Trock BJ, Hilakivi-Clarke L, Clarke R (2006) Meta-analysis of soy intake and breast cancer risk. J Natl Cancer Inst 98: 459-471

Turck D (2007) Soy protein for infant feeding: what do we know? Curr Opin Clin Nutr Metab Care 10: 360-365

Vissac-Sabatier C, Coxam V, Dechelotte P, Picherit C, Horcajada MN, Davicco MJ, Lebecque P, Bignon YJ, Bernard-Gallon D (2003) Phytoestrogen-rich diets modulate expression of Brca1 and Brca2 tumor suppressor genes in mammary glands of female Wistar rats. Cancer Res 63: $6607-6612$

Wagner KU, Smith GH (2005) Pregnancy and stem cell behavior. J Mammary Gland Biol Neoplasia 10: 25-36

Warri AM, Saarinen NM, Makela SI (2007) Can modulation of mammary gland development by dietary factors support breast cancer prevention? Horm Res 68: 248-260

Woodward WA, Chen MS, Behbod F, Rosen JM (2005) On mammary stem cells. J Cell Sci 118: $3585-3594$

Wu AH, Wan P, Hankin J, Tseng CC, Yu MC, Pike MC (2002) Adolescent and adult soy intake and risk of breast cancer in Asian-Americans. Carcinogenesis 23: $1491-1496$

Wu AH, Yu MC, Tseng CC, Pike MC (2008) Epidemiology of soy exposures and breast cancer risk. Br J Cancer 98: 9-14

Yang X, Edgerton SM, Kosanke SD, Mason TL, Alvarez KM, Liu N, Chatterton RT, Liu B, Wang Q, Kim A, Murthy S, Thor AD (2003) Hormonal and dietary modulation of mammary carcinogenesis in mouse mammary tumor virus-c-erbB-2 transgenic mice. Cancer Res 63: $2425-2433$ 